\title{
Corporate Governance and Financial Distress in the Banking Industry: Nigerian Experience
}

\author{
Ayoola Tajudeen John ${ }^{1},{ }^{2}$ Obokoh Lawrence Ogechukwu \\ ${ }^{1}$ Obafemi Awolowo University, Ile-Ife, Nigeria \\ ${ }^{2}$ Cape Peninsula University of Technology, Cape Town, South Africa \\ alabiayoolaaca@yahoo.com, lechukwu2001@yahoo.com
}

\begin{abstract}
The study investigates the effect of corporate governance on financial distress in the Nigerian banking industry and examines the discriminatory power of corporate governance mechanism of the board, audit committee, executive management and auditor in one model for financial distress prediction. Secondary data obtained from annual financial statements of twenty banks between 2005 and 2015 were used for the study. The data were analyzed using descriptive statistics and generalized quantile regression model. The empirical evidence from the study suggests that financially distressed banks are characterized by large board size with members who may not be well versed in banking complexities, chairmen and CEOs with significant shareholding both individually and collectively. Furthermore, the evidence also shows that distressed banks suffer major decline in customer deposits despite increase in size. The study concludes that financial distress can be caused by poor corporate governance mechanism.
\end{abstract}

Keywords: Banking industry, corporate governance, financial distress, Nigerian experience

\section{Introduction}

Banks play a very important role in the society, occupying critical position in the process of promoting economic growth (Wanke, Barros and Faria, 2015). As a result of this role, a properly functioning banking sector is crucial for the growth of an economy and the stability of the financial system (Hoggarth, Reis and Saporta, 2002). National governments through their regulatory agencies have shown concern towards the proper functioning of the banking industry and have therefore regulated the industry. However, despite the supervision and regulatory role of government, the industry has been periodically characterized by financial distress thereby resulting in huge loss of shareholders' funds and erosion of public confidence in the system (Lang and Schmidt, 2016). Financial distress in banking remains a significant issue for owners, managers and the public (Simpson and Gleason, 1999) and early warning signals have been advocated as essential to limit the potential adverse effect of financial distress on the economy (Li, Crooks, and Andreeva, 2014). Various models have been used in financial distress prediction starting with diverse statistical methods such as Altman's (1968) multiple discriminant analysis, Ohlson's (1980) logistic regression; Intelligent models such as neural network model, support vector machine, genetic algorithm, genetic programming and others. All of these methods focused on the explanatory powers of financial, accounting and market variables (Manzaneque, Priego and Merino, 2016).

However, in the early 1990s, another strand of research that explores corporate governance variables and their roles in predicting financial distress emerged in literature (Chan, Chou, Lin, and Liu, 2016). These authors have argued that economic and financial data alone do not provide sufficient predictive power of future distress, hence, the need to consider variables representative of corporate governance characteristics (Heremans, 2007; Chen, 2008; Chang, 2009). Amendola, Restaino and Sensini (2015) specifically argued that the structure of the firm's board of directors and ownership and the interaction among them can affect the probability of failure. While Zeitun (2009) states that the agency problem between the shareholders of a company and the management leads to inefficiency in terms of ownership concentration. The 2007-2009 global financial crises triggered a more robust discussion of corporate governance and brought it to the front burner of international dimension (Villanueva-Villar, Rivo-Lopez and Lago-Penas, 2016). According to Iqbal, Strobl and Vahamaa (2015) believe that politicians, banking supervisors and other authorities attributed financial crises to the flaws in the corporate governance practices of financial institutions (Kirkpatrick, 2009; Haldane, 2012).

Corporate governance is a mechanism that is used to protect the rights of different stakeholders. It specifies the distribution of such rights and responsibilities among the different actors in the corporation such as the shareholders, board, managers, and others. It spells out the rules and procedures for making decisions in 
corporate affairs (OECD, 1999). Corporate governance participants are the board of directors (BODs), audit committee, shareholders, top management and the auditors (Rezaee, 2007). No corporate governance would be necessary if management acted in the best interest of shareholders and if the board members effectively discharge their fiduciary duties and professional responsibilities. Corporate governance is needed to avoid concentration of power in the hands of management and to create an effective system of checks and balances to appropriately balance power-sharing authority among shareholders, board, management, and, to a lesser extent, other stakeholders. It is a monitoring mechanism for assessing corporate responsibility and accountability through the board, audit committee, management and auditors in order to serve and protect the interest of investors (Rezaee and Riley, 2010). There is substantial evidence that one corporate governance size does not always fit all firms in all countries as governance structure differs from one country to another (Black, de Carvalho and Gorga, 2012). Though there is a body of literature that highlights the importance of corporate governance and its influence on the likelihood of financial distress, the contribution has been limited because of the legal processes and definitions of financial distress which vary from one country to another (Manzaneque et al., 2016).

This study is justified because it extends the analysis of financial distress to other geographical contexts. Additionally, a more comprehensive determination of financial distress situation will contribute to the existing literature (Crespi-Cladera and Pascual-Fuster, 2015). Furthermore, the focus of most studies on corporate governance and financial distress centers on board structure and/or ownership characteristics with the exclusion of other participants such as the shareholders, audit committee and the auditor in the same model (Villanueva-Villar et al., 2016). To this end, the study raises the question as to how can we test the discriminatory powers of corporate governance mechanism of the board, external auditors, shareholders, and ownership structure in one model that can predict financial distress in the Nigerian banking industry? In view of this, the study investigates the effect of corporate governance on financial distress and examines the discriminatory power of corporate governance mechanism of the board, audit committee, executive management and auditor in one model for financial distress prediction in the Nigerian banking industry. The rest of the paper is organized as follows: Section 2 provides the review of relevant literature. Section 3 describes the data and methodological approach while Section 4 discusses the results. The conclusion and policy recommendation are provided in Section 5.

\section{Literature Review}

Financial distress is a broad concept used to describe situations in which firms face financial difficulty. The most common terms used interchangeably for financial distress are 'failure', 'default', 'insolvency', and 'bankruptcy' (Geng, Bose, and Chen, 2015). However, bankruptcy is the extreme and irredeemable outcome of financial distress and as such many financially distressed firms escape bankruptcy due to early reconstruction of operations. There are many definitions of financial distress because different countries have different accounting procedures and rules. It is generally believed that it is a situation where operating cash flow does not exceed negative net assets (Li et al., 2014). Geng et al. (2015) state that some of the methods that have been used for financial distress prediction include discriminant analysis, logit or probit regression model, linear conditional probability models, neural network, decision trees, case based reasoning, genetic algorithm, rough sets, support vector machine, and others. However, the assumptions underlying the majority of these methods are far from real world situation. Extant research has focused on the discovery of better models for financial distress prediction because of the limitations of statistical techniques that have been extensively used over the years.

Financial Distress in the Nigerian Banking Industry: In Nigeria, financial distress has been a pervasive issue as the banking sector has been periodically characterized by financial distress. The history of Nigerian banking distress can be conveniently divided into three eras namely: the era between (i) 1940s and 1950s; (ii) 1989 and 1998; and (iii) 2007 and 2010. The distress experienced between 1940s and 1950s was attributable to mismanagement of assets, lack of adequate capital and managerial expertise due to untrained personnel to mention but a few (Adekanye, 1983; Osaze and Anao, 1990). The second era of financial crisis was first observed in 1989 when there was mass withdrawal of deposits by government agencies, this situation worsened in 1993 after the annulled June 12 presidential election. This led to the collapse of the inter-bank market which later spread to all segments of the financial system (Ailemen, 2003; Hecko, 2007; 
Sanusi, 2010). The third era of financial distress crisis happened in the aftermath of the 2007- 2009 global financial crises that prompted the Central Bank of Nigeria (CBN) to provide funding support to the banking industry. The third era of distress was partly explained by the global financial crisis, but, it was evident that the banks contributed in no small measure to its escalation. During this period, the CBN ordered a special investigation into the financial condition of the country's 24 banks. At the end of the investigation, the boards of eight banks were dismissed on the grounds of insider abuses, fraud, poor risk management, inadequate capital and corporate governance issues (Osaze, 2011; Sanusi, 2011). Consequently, the CBN injected fresh Tier II capital amounting to US $\$ 4.1$ billion into the banking industry (Sanusi, 2010; Fadare, 2011). Financial distress is not a new phenomenon in the Nigerian banking sector. Despite this, only a few studies have been carried out on this issue, almost all of which utilized logit/probit models and focused on bankruptcy, which is the final outcome of financial distress.

Concept of Corporate Governance and the Nigerian Banking Industry: Various definitions reflecting different perspectives of corporate governance exist in the literature because of its multidimensional nature. Cadbury (1992) defines corporate governance as the mechanisms that are used to protect the interests of different stakeholders. Though studies have attempted to develop corporate governance indices that aggregate a number of mechanisms to investigate how corporate governance relates to performance, the literature indicates that there is no single, standard corporate governance index that can be considered as "one size fits all" (Munisi and Randoy, 2013; Rygh, 2016). The various views on corporate governance relates to different cultural contexts and intellectual background (Idam, 2015). In Nigeria, corporate governance studies have grown rapidly in recent times following the dismissal of the chief executives of eight banks by the Central Bank of Nigeria on the grounds of corporate governance issues among other factors. The CBN alleged that the 2007-2010 banking crisis in Nigeria was caused partly by poor corporate governance by banks' management. This revelation generated a lot of interest in corporate governance studies. However, the studies on corporate governance have been largely related to performance with little or no studies on the effect of corporate governance on financial distress. Thus, the role of corporate governance in financial distress has been largely neglected. According to Manzaneque et al. (2016), previous empirical debate on financial distress focuses on explanatory powers of financial and accounting information applying diverse statistical methods such as linear discriminant analysis and logit/probit analysis. Several researchers have argued that economic and financial data alone do not provide sufficient predictive power of distress and is therefore necessary to include variables representative of corporate governance characteristics to improve the predictive power of the model (Chen, 2008; Chang, 2009; Lakshan and Wijekoon, 2012).

Review of Theories applicable to the Study: The theoretical framework underlying this study includes theories such as the agency theory, stewardship theory, resource dependency theory, and the theoretical institutional perspective $(\mathrm{Xu}, 2007)$. The agency theory is the most prominent and rooted in the idea of separation of business ownership and control between shareholders and managers. The agency problem arises out of the possibility of opportunistic behavior on the part of the agents against the welfare of their principals (Duhnfort, Klein, and Lampenius, 2008; Idam, 2015). However, agency theory is limited because it does not explain the multidimensional complexity and character of corporate governance phenomenon (Adegbite, 2015; Briano-Turrent and Rodriguez-Ariza, 2016). The stewardship theory sees managers as good stewards of the business organization who work diligently to attain high level of corporate profit and shareholders' returns. The stakeholder theory on the other hand sees the organization as a system of stakeholders operating under a wider societal system, which provides the input, market, legal and other operational infrastructure for the organization. The theory advocates that stakeholders, including employees, customers, suppliers, communities and other groups, are directly or indirectly affected by the organization's operations, and should have a representation on the board of directors. The resource-dependency theory categorizes corporate governance mechanisms as firm's resources and suggests that the resources possessed by a firm are the primary determinants of its performance (Wernerfelt, 1984; Bernadette and Corina, 2015). Empirical studies such as Letza, Sun, and Kirkbride (2004) and Garcia-Torea, Fenandez-Feijoo and de la Cuesta (2016) have established that the shareholder and stakeholder perspectives are the most relevant approaches for analyzing the firm's corporate governance. While the former considers that the key aim of corporate governance is the protection of shareholder interests, the latter advocates that the main objective of corporate governance is to guarantee the interests of all of the firm's stakeholders. Following the works of 
Money and Schepers (2007), this study extends the scope of corporate governance by considering shareholders as a type of stakeholder with rights equal to those held by other stakeholders.

\section{Methodology}

Data and Sample: The population of the study comprised deposit money banks operating in Nigeria between 2005 and 2015, of which the number varied from 25 in 2005 and 22 in 2015. The sample consisted of an unbalanced panel data set obtained from the audited annual financial statements of 20 banks for which information was available during the period under consideration.

Model Specification and Measurement of Variables: To test for the effect of corporate governance on financial distress in the Nigerian banking industry, we adopted the following model:

$$
Y_{i t}=\beta_{0}+\beta_{1} X_{1 i t}+\beta_{2} X_{2 i t}+\beta_{3} X_{3 i t} \ldots \ldots \ldots \ldots \ldots \ldots \ldots \ldots+\beta_{21} X_{21 i t}+\varepsilon_{i t}
$$

Dependent Variable: The dependent variable is financial distress. Different indices have been used to capture financial distress. Following the works of Wanke, Barros and Faria (2015), Cielen, Peeters and Vanhoof (2004), Premachandra, Bhabra and Sueyoshi (2009), Premachandra, Chen and Watson (2011), Shiri and Salehi (2012), and Li et al. (2014), this study adopted efficiency scores determined through data envelopment analysis (DEA) as proxies of financial distress. The major underlying hypothesis is that lower efficiency levels imply greater chance for an eventual financial distress situation in the future and efficiency measures can successfully distinguish between healthy and distressed banks (Wanke et al., 2015). According to Li et al. (2014), it is logical to assume that efficiency is associated with the probability of financial distress. Empirical studies have established that there is significant difference of scores between healthy and failing banks and the difference increases as the date of failure approaches (Barr, Seiford and Siems, 1993; Geng, Bose and Chen, 2015). The efficiency scores lie between ' 1 ' and ' 0 '. The value ' 0 ' indicates that the evaluated bank is on the financial distress frontier and the value ' 1 ' indicates that the evaluated bank is healthy. Intensity of financial distress decreases as the score moves from ' 0 ' to ' 1 ' (Shetty, Pakkala and Mallikarjunappa, 2012). To define input and output variables, we follow the intermediation approach of Sealey and Lindley (1977) which justifies the approach on the ground that the primary function of banks is to channel financial funds from savers to investors. In line with previous studies, we define three input and three output variables. We follow the original idea of DEA that inputs and outputs are measured as absolute amounts rather than as ratios (Li et al., 2014). Thus, the input variables are gross revenue, profit before interest and tax, and deposit, while the output variables are non-performing loans, total liabilities and staff cost.

Independent Variables: The independent variables and their a priori expectations based on literature are as shown in Table 1. This includes 21 indices of corporate governance variables and control variables over four governance mechanisms of the board, shareholder, external audit and ownership structure.

Control Variables: Following prior studies such as Shehzad, de Haan and Scholtens (2010), Munisi and Randoy (2013), and Rygh (2016), we include the following control variables: (i) size measured as logarithm of total assets: larger banks may have better performance because of economies of scale; (ii) capital measured as equity to assets: banks with high capital may have more resources that may allow them to adopt good practices; (iii) leverage measured as liabilities to assets: debt may affect company performance as it reduces the free cash flow, moreover, highly leveraged banks are more closely monitored by debt providers, who may put pressure on management to adopt good governance practices; (iv) business model measured as net loans to total assets; (v) managers' efficiency measured as cost to income ratio; (vi) profitability measured as profit before interest and tax: profitability has a significant impact on market valuation as investors accept a premium for owning more profitable companies; and (vii) growth measured by growth in deposit as deposit may influence a bank's financial market performance and corporate governance practices.

Estimation Techniques: Two-stage estimation process was adopted for the investigation of the effect of corporate governance on financial distress in the Nigerian banking industry. The first stage involved determining distress scores using DEA efficiency frontier, while the second stage involved determining the 
effect of corporate governance on financial distress using a variety of techniques in line with previous studies (Simar and Wilson, 2011; Johnson and Kuosmanen, 2012). A large number of studies have used a variety of techniques including the standard linear regression model, fixed and random effects regression models, censored normal regression model (that is, Tobit model), Simar and Wilson (2007) model, among others. The standard linear model including fixed and random effects regression models have been considered inappropriate for the second-stage DEA because they allow predicted values to lie outside the admissible interval $(0,1)$ determined by the measurement scale (Papke and Wooldridge, 2008; Pericoli, Pierucci and Ventura, 2013). The two-limit Tobit regression has also been considered as a conceptually flawed model for proportional data. This is because DEA scores are not observationally censored by Tobit model but are defined only over the interval (Simar and Wilson, 2007; Cook, Kieschnick and McCullough, 2008; McDonald, 2009).

A model that has been proposed as an effective alternative to the two flawed techniques is quantile regression model (Rousseliere, 2014; Shawtari, Salem, Hussain, Alaeddin and Thabit, 2016). As the dependent variable takes the ranges between upper and lower values $(0,1)$, it results in having a number of percentiles of dependent variable, in which its relationship with corporate governance varies from one percentile to another. Therefore, estimating the relationship based on the averaged figures or means may not reflect the reality and would hide some information due to heterogeneity of the data (Chi, Huang, and Xie, 2015). Consequently, it is believed that using the quantile regression would provide a better estimation for the relationship between dependent and independent variables as the analysis estimate the relationship at any point conditional on the distribution of the dependent variable (Shawtari et al., 2016).

Quantile regression relaxes one of the fundamental conditions of ordinary least square (OLS) and permits the estimation of various quantile functions, helping to examine in particular the tail behaviors of that distribution (Parente and Santos-Silva, 2016). It departs from conditional-mean models as it allows for heterogeneity and deal with endogeneity problem associated with governance studies (KoutsomanoliFilippaki and Mamatzakis, 2011; Liu and Miu, 2010). It is invariant to monotonic transformations and robust to outliers (Baum, 2013). Also, it is asymptotically consistent and valid under intra-cluster correlation; and robust even when the error term is heteroskedastic and non-normally distributed (Aldieri and Vinci, 2017; Koutsomanoli-Filippaki and Mamatzakis, 2011; Powell, 2014; Powell, 2016). A version of quantile regression model known as the generalized quantile regression model was applied to estimate the effect of financial distress in the second stage analysis. The generalized quantile estimator addresses a fundamental problem posed by traditional quantile estimators, namely: inclusion of additional covariates alters the interpretation of the estimated coefficient on the treatment variable (Powell, 2014). The generalized quantile estimator implemented by "genqreg in STATA application" addresses this problem and produces unconditional quantile treatment effects even in the presence of additional control variables (Powell, 2016).

\section{Findings}

Descriptive Statistics: Table 2 depicts descriptive statistics for the dependent variable, independent variables and control variables used in the empirical analysis. For the dependent variable, we found that the sample firms have a mean financial distress level of approximately 50\%. The average board is composed of about eleven members and the proportion of independent directors is around 53\% of the total board members. The board meets for an average of 7 times per year. Regarding shareholding, the chairman and the chief executive officer hold about $2 \%$ each of shares, the largest shareholder controls about $4 \%$, while insider management comprising of all directors and the chief executive officer hold about $11 \%$ which indicate a fair alignment of interests between ownership and the board. The institutional shareholders hold about $20 \%$ in shareholding.

Financial Distress Scores (First Stage): The study adopted a two-stage approach in the analysis of the effect of corporate governance on financial distress in Nigerian banks. In the first stage, DEA efficiency estimator was used to obtain distress scores proxied by efficiency scores for individual banks as the dependent variable. An input-oriented, variable return to scale (VRS) approach which is based on the assumption that banks have more control over their inputs than outputs was adopted. Financial distress was modeled with technical efficiency scores where efficiency scores of " 1 " means healthy banks while efficiency scores between " 0 " and 
"0.9" suggest different levels of inefficiencies. Following the works of Kumar and Gulati (2008), we utilized the quartile values of efficiency scores as cut-off points to segregate the banks into three categories as follows:

Quartile values between $0.1-0.5=$ distressed banks

Quartile values between $0.6-0.9=$ marginally healthy banks

Quartile values of $1 \quad=$ healthy banks

Generalized Quantile Regression Analysis Results (Second Stage): Table 3 shows the second stage analyses of the effect of corporate governance variables on financial distress in Nigerian banking industry. The results of the generalized quantile regression model (using quartile values between 0.1 and 0.5 for distressed banks) show that nine variables are statistically significant at 5\% level. Board size (lnbsize) presents a positive coefficient on financial distress. The variable shows a statistically significant relationship with financial distress at a 5\% significance level. This suggests that distressed banks are characterized with a large board that may be ignorant of the dynamics of the banking industry. Small boards are more likely to monitor management better since their members are less able to hide in a large group. They are also more likely to be involved in strategy formation and abler to arrive at decisions faster than larger ones. This finding is consistent with the work of Briano-Turrent \& Rodriguez-Ariza (2016) which associate large boards with distress. This study is at variance with the resource dependence theory which argues that large boards offer better advantages than small boards (Manzaneque et al., 2016).

Board independence (bind) presents a positive coefficient and statistically significant effect on financial distress at a 5\% significance level. This indicates that distressed banks have more non-executive directors on their boards who may not contribute positively to the progress of the banks. Independent directors may lack in-depth knowledge of the internal workings of the banks on whose boards they sit. They may also lack the financial expertise to understand the complexity of the securitization processes banks engage in and the risks involved. This finding is in alignment with the works of Adams $(2010,2012)$ which concludes that board independence may not necessarily be beneficial for banks, as independent directors may not always have the expertise necessary to oversee banking firms. This study is at variance with the agency theory which posits that the proportion of independent directors is negatively related to financial distress (Manzaneque et al., 2016). Ownership diffusion (Inshares) presents a negative coefficient and statistically significant effect on financial distress at $5 \%$. This implies that distressed banks have less diffused ownership or fewer numbers of shares. The chairman (chair) share ownership presents a positive coefficient and statistically significant effect on financial distress at 5\% significance level, implying that in distressed banks, chairmen hold a significant number of controlling shares.

Chief Executive Officers (CEO) share ownership also present a positive coefficient and statistically significant effect on financial distress at 5\% significance level, with the implication that in distressed banks, chief executive officers also hold significant number of controlling shares. Insider ownership (insider) representing the shares owned by all the directors including the CEO presents a negative coefficient and a statistically significant indirect effect on financial distress. Insider shareholders are considered to have access to a greater extent and better quality of bank-specific information. The implication of a negative effect could be that insider shareholders have access to inside information of the poor financial state of the banks and the quick divestment of shares by the directors. Size (bind) proxied by log of assets presents a positive coefficient and statistically significant direct effect on financial distress at 5\%. This suggests that as size increases, the banks might face more risk events. This finding is in alignment with the works of Wang and Hsu (2013) which document that larger banks are associated with higher systemic risk. Growth (growth) proxied by customer deposits presents a negative coefficient and statistically significant indirect effect on financial distress at a 5\% significance level, implying that the propensity to withdraw deposits increases with the magnitude of financial distress. This finding is in line with the works of Goldstein and Pauzner (2005) and Egan, Hortacsu, and Matvos (2015) who affirm that distressed banks experience large decline in customer deposits.

In Nigeria, banks are supervised by regulatory organs such as the Central Bank of Nigeria and the Securities and Exchange Commission and governed by their board of directors. Various initiatives have been carried out by the regulatory authorities to improve corporate governance in Nigeria including but not limited to the creation of codes of corporate governance. Some of the provisions of the code include a pegging of direct and 
indirect equity holding in any bank to $10 \%$ and an equity holding of above $10 \%$ by any investor subject to the regulatory prior approval; a maximum board size of 20 directors; an appointment of a chief compliance officer, among other rules (Uche, 2014). Some studies on corporate governance in Nigeria focused on the structure and the distribution of rights and responsibilities among the different corporate governance participants (Garuba and Otomewo, 2015; Ad eyemi and Olowu, 2013; Uche, 2014). Few studies constructed a corporate governance index and evaluated its effect on banks' performance (Ajala, Amuda and Arulogun, 2012). The outcome of studies on corporate governance in Nigerian banks revealed that corporate governance impacted on performance (Thomas and Mohammed, 2011; Sanda, Mikailu and Garba, 2005; Kajola, 2008; James and Okafor, 2011; Ahmad and Mansur, 2012; Akingunola, Adekunle, and Adedipe, 2013).

\section{Table 1: Measurement and a priori Expectation of Independent Variables}

\begin{tabular}{|c|c|c|c|}
\hline S/NO & $\begin{array}{l}\text { VARIABLES } \\
\text { BOARD STRUCTURE }\end{array}$ & MEASUREMENT & A PRIORI \\
\hline 1 & Board Size (lnbs) & Log of Total Directors & \pm \\
\hline 2 & Board Independence (bind) & Non-Executive Directors/ Total Directors & \pm \\
\hline 3 & Board Salaries (bsal) & Board Compensation/ Total Compensation & \pm \\
\hline 4 & Board Meetings (lnbmtg) & Log of Total Number of Meetings & \pm \\
\hline 5 & Female Directorship (bfemale) & $\begin{array}{l}\text { Number of Female Directors/ Total } \\
\text { Directors }\end{array}$ & \pm \\
\hline 6 & $\begin{array}{l}\text { Foreign Directorship (bforeign) } \\
\text { OWNERSHIP STRUCTURE }\end{array}$ & Foreign Directors/ Total Directors & \pm \\
\hline 7 & $\begin{array}{l}\text { Chairman's share ownership } \\
\text { (chair) }\end{array}$ & Chairman's Shares/ Total Number of Shares & \pm \\
\hline 8 & CEO's share ownership (ceo) & CEO's Shares/ Total Number of Shares & \pm \\
\hline 9 & $\begin{array}{l}\text { Chairman \& CEO' share ownership } \\
\text { combined (chairceo) }\end{array}$ & $\begin{array}{l}\text { Chairman's and CEO's Shares combined/ } \\
\text { Total Number of Shares }\end{array}$ & \pm \\
\hline 10 & Insider Ownership (insider) & Insider's Shares/ Total Number of Shares & \pm \\
\hline 11 & Institutional Ownership (inst) & $\begin{array}{l}\text { Institutional Ownership Shares/ Total } \\
\text { Number of Shares }\end{array}$ & \pm \\
\hline 12 & $\begin{array}{l}\text { Largest Shareholders (largest) } \\
\text { SHAREHOLDERS }\end{array}$ & Largest shareholder/Total Shares & \pm \\
\hline 13 & Total number of shares (lnshares) & Log of total number of shares & -- \\
\hline 14 & $\begin{array}{l}\text { Equity (lnequity) } \\
\text { EXTERNAL AUDITING }\end{array}$ & Log of equity & -- \\
\hline 15 & Auditor's Opinion (opinion) & $\begin{array}{l}1=\text { Qualified Audit Opinion } \\
0=\text { Favorable Audit Opinion }\end{array}$ & -- \\
\hline & CONTROL VARIABLES & & \\
\hline 16 & Size (size) & Log of Total Assets & \pm \\
\hline 17 & Capital (capital) & Equity/ Total Assets & -- \\
\hline 18 & Leverage (leverage) & Liabilities/Total Assets & + \\
\hline 19 & Management Efficiency (efficiency) & Operating Cost/ Operating Income & -- \\
\hline 20 & Profitability (profit) & Profit before Interest and Tax & -- \\
\hline 21 & Growth(growth) & Log of Deposit & -- \\
\hline
\end{tabular}

Source: Shawtari, Salem, Hussain, Alaeddin, and Thabit (2016); Li, Crooks and Andreeva $\quad$ (2014); Premachandra, Chen and Watson (2011); Chang (2009); Chen (2008). 


\begin{tabular}{l} 
Journal of Economics and Behavioral Studies (ISSN: 2220-6140) \\
Vol. 10, No. 1, pp. 182-193, February 2018 \\
\hline \hline
\end{tabular}

Table 2: Descriptive Statistics of Variables

\begin{tabular}{|c|c|c|c|c|c|}
\hline Variables & Mean & Median & Std. Dev & Min & Max \\
\hline distress & 0.509 & 0.537 & 0.341 & 0.100 & 1.000 \\
\hline lnbsize & 1.144 & 1.146 & 0.096 & 0.845 & 1.322 \\
\hline bind & 0.529 & 0.533 & 0.085 & 0.200 & 0.750 \\
\hline bsal & 0.247 & 0.016 & 0.037 & 0.001 & 0.382 \\
\hline lnbmtg & 0.755 & 0.699 & 1.165 & 0.602 & 1.380 \\
\hline bfemale & 0.095 & 0.071 & 0.088 & 0.000 & 0.429 \\
\hline bforeign & 0.043 & 0.000 & 0.066 & 0.000 & 0.316 \\
\hline lnshares & 4.134 & 4.142 & 0.249 & 3.486 & 4.639 \\
\hline lnequity & 4.915 & 5.030 & 0.521 & 3.107 & 6.023 \\
\hline chair & 0.012 & 0.001 & 0.024 & 0.000 & 0.146 \\
\hline ceo & 0.014 & 0.003 & 0.022 & 0.000 & 0.095 \\
\hline chairceo & 0.027 & 0.009 & 0.035 & 0.001 & 0.148 \\
\hline insider & 0.112 & 0.064 & 0.140 & 0.001 & 0.907 \\
\hline inst & 0.201 & 0.119 & 0.254 & 0.000 & 1.000 \\
\hline largest & 0.044 & 0.030 & 0.048 & 0.000 & 0.249 \\
\hline opinion & 0.127 & 0.000 & 0.334 & 0.000 & 1.000 \\
\hline lnsize & 5.639 & 5.707 & 0.441 & 4.289 & 6.443 \\
\hline capital & 0.130 & 0.151 & 0.215 & -1.042 & 0.668 \\
\hline leverage & 0.883 & 0.849 & 0.195 & 0.410 & 2.042 \\
\hline efficiency & 0.828 & 0.660 & 0.814 & 0.276 & 9.483 \\
\hline profit & 3.601 & 3.973 & 1.191 & 0.000 & 5.043 \\
\hline growth & 5.565 & 5.607 & 0.459 & 4.093 & 6.410 \\
\hline
\end{tabular}

Source: Authors' computation, 2017

Table 3: Generalized Quantile Regression Model Results

\begin{tabular}{|c|c|c|c|}
\hline Variables & Coefficient & Z- Statistics & Prob-Significance \\
\hline \multicolumn{4}{|c|}{$\begin{array}{l}\text { Dependent Variable: } \\
\text { distress }\end{array}$} \\
\hline \multicolumn{4}{|c|}{ Independent Variables } \\
\hline lnbsize & 0.9655619 & 2.00 & $0.045^{* *}$ \\
\hline bind & 1.100266 & 2.27 & $0.023 * *$ \\
\hline bsal & -1.58429 & -1.09 & 0.275 \\
\hline lnbmtg & 0.0442366 & 0.17 & 0.867 \\
\hline bfemale & -0.3131937 & -0.88 & 0.377 \\
\hline bforeign & -0.4237746 & -1.23 & 0.219 \\
\hline lnshares & -0.4727464 & -2.89 & $0.004 * * *$ \\
\hline lnequity & 0.2549368 & 1.04 & 0.297 \\
\hline chair & 4458.867 & 3.14 & $0.002^{* * *}$ \\
\hline ceo & 4452.235 & 3.14 & $0.002^{* * *}$ \\
\hline chairceo & -4453.376 & -3.14 & $0.002^{* * *}$ \\
\hline insider & -1.485981 & -2.42 & $0.016^{* *}$ \\
\hline inst & 0.0682644 & 0.47 & 0.639 \\
\hline largest & 1.61275 & 0.98 & 0.329 \\
\hline opinion & 0.0391501 & 0.24 & 0.811 \\
\hline $\operatorname{lnsize}$ & 1.3501 & 3.21 & $0.001^{* * *}$ \\
\hline capital & -0.4301007 & -1.24 & 0.214 \\
\hline leverage & -0.7988084 & -1.17 & 0.240 \\
\hline efficiency & -0.2150012 & -0.89 & 0.373 \\
\hline profit & 0.0008392 & 0.03 & 0.978 \\
\hline growth & -1.012666 & -2.37 & $0.018^{* *}$ \\
\hline _cons & -1.468274 & -1.85 & 0.065 \\
\hline
\end{tabular}

Source: Authors' computation, 2017. 
This table shows the generalized quantile regression model analysis of the effect of corporate governance on financial distress in Nigeria. The first column shows the variables; the second column shows the model coefficient. The third column displays the z-statistic while the fourth column indicates the significance at 1,5 and 10 denoted by ${ }^{* * *}, * *$ and $*$ respectively.

\section{Conclusion and Policy Recommendations}

This study examined the effect of corporate governance on financial distress in the Nigerian banking industry. We analyzed a sample of 20 banks over the period between 2005 and 2015 and measured financial distress by DEA technical efficiency following previous studies and corporate governance variables along board characteristics, ownership structure, shareholding, external audit opinion and control variables. Using generalized quantile regression model, we found that corporate governance variables which significantly influence financial distress are board size; independence; share ownership by chairmen, chief executive officers and directors; size; and deposit. The empirical results suggest that distressed banks are characterized by large board size and non-executive board members who may lack financial expertise and in-depth knowledge of the complexity of banking businesses. Share ownership by chairmen and CEOs both individually and jointly are significantly and positively related to financial distress suggesting that the banks may have been managed to fulfill some personnel interest which contradicts established opinion that the interest of both the chairman and CEO will align where share ownership by chairman and CEO are significant. Lastly, distressed banks experience massive withdrawal of customer deposits and divestment by insider management who also double as shareholders. Consequently, for corporate governance policy implementation, banks should employ smaller board size with members having the requisite banking knowledge, which will allow them to run efficiently. The regulatory authority should strengthen corporate governance mechanism that will help to reduce the incidence of financial distress and improve uniform mechanisms of control.

\section{References}

Adams, R. B. (2010). Governance at Banking Institutions. In H. K. Baker, \& R. Andersen (Eds.), Corporate Governance. NJ, Hoboken: Wiley \& Sons.

Adams, R. B. (2012). Governance and the Financial Crisis. International Review of Finance, 12(1), 7-38.

Adegbite, E. (2015). Good Corporate Governance in Nigeria: Antecedents, Propositions and Peculiarities. International Business Review, 24(2), 319-330.

Adekanye, F. (1983). The Elements of Banking in Nigeria (4th ed.). Lagos: F \& A Publications.

Adeyemi, B. \& Olowu, A. O. (2013). Corporate Governance: Has the Nigerian Banking Sector Learnt any Lesson? International Journal of Business and Social Research, 3(2), 49-59.

Ahmad, B. A. \& Mansur, L. K. (2012). Corporate Governance and Financial Performance of Banks in the Post Consolidation Era in Nigeria. International Journal of Social Sciences and Humanity Studies, 4(2), 2736.

Ailemen, I. (2003). Bank Distress: Concepts, Causes and Magnitude: Role of Trade Union and Bank Management. The Nigerian Banker, October-December, 1-8.

Ajala, O. A., Amuda, T. \& Arunlogun, L. (2012). Evaluating the Effects of Corporate Governance on Performance of Nigerian Banking Sector. Review of Contemporary Business Research, 1(1), 32-42.

Akingunola, R. O., Adekunle, O. A. \& Adedipe, O. A. (2013). Corporate Governance and Bank's Performance in Nigeria. European Journal of Business and Social Sciences, 2(8), 89-111.

Aldieri, L. \& Vinci, C. (2017). Quantile Regression for Panel Data: An Empirical Approach for Knowledge Spillovers Endogeneity. Germany: MPRA.

Altman, E. I. (1968). Financial Ratios, Discriminant Analysis and the Prediction of Corporate Bankruptcy. The Journal of Finance, 23(4), 589-609.

Amendola, A., Restaino, M. \& Sensini, L. (2015). An analysis of the determinants of financial distress in Italy: A competing risks approach. International Review of Economics and Finance, 37, 33-41.

Barr, R. S., Seiford, L. M. \& Siems, T. F. (1993). An Envelopment Analysis Approach to Measuring the Managerial Efficiency of Banks. Annals of Operations Research, 45(1), 1-19.

Baum, C. F. (2013). Quantile Regression. Boston College. 
Bernadette, J. J. \& Corina, J. (2015). Corporate Governance Mechanisms and Bank Performance: ResourceBased View. Procedia Economics and Finance, 31, 117-123.

Black, B. S., deCarvalho, A. G. \& Gorga, E. (2012). What Matters and for Which Firms for Corporate Governance in Emerging Markets? Evidence from Brazil and other BRIK Countries. Journal of Corporate Finance, 18, 934-952.

Briano-Turrent, G. D. \& Rodriguez-Ariza, L. (2016). Corporate Governance Ratings on Listed Companies: An Institutional Perspective in Latin America. European Journal of Management and Business Economics, $25,63-75$.

Cadbury. (1992). Report of the Committee on the Financial Aspects of Corporate Governance. London: The Cadbury Report.

Chan, C., Chou, D., Lin, J. \& Liu, F. (2016). The Role of Corporate Governance in Forecasting Bankruptcy: Pre and Post SOX Enactment. North American Journal of Economics and Finance, 35, 166-188.

Chang, C. (2009). The Corporate Governance Characteristics of Financially Distressed Firms: Evidence from Taiwan. Journal of American Academy of Business, 15, 125-132.

Chen, H. (2008). The Timescale Effects of Corporate Governance Measure on Predicting Financial Distress. Review of Pacific Basin Financial Markets and Policies, 11, 35-46.

Chi, W., Huang, H. \& Xie, H. (2015). A Quantile Regression Analysis on Corporate Governance and the Cost of Bank Loans: A Research Note. Review of Accounting and Finance, 14(1), 2-19.

Cielen, A., Peeters, L. \& Vanhoof, K. (2004). Bankruptcy Prediction Using a Data Envelopment Analysis. European Journal of Operational Research, 154, 526-532.

Cook, D. O., Kieschnick, R. \& McCullough, B. D. (2008). Regression Analysis of Proportions in Finance with Self Selection. Journal of Empirical Finance, 15, 860-867.

Crespi-Cladera, R. \& Pascual-Fuster, B. (2015). Executive Directors' Pay, Networks and Operating Performance: The Influence of Ownership Structure. Journal of Accounting and Public Policy, 34, 175203.

Duhnfort, A. M., Klein, C. \& Lampenius, N. (2008). Theoretical Foundations of Corporate Governance Revisited: A Critical Review. Corporate Governance and Control, 6(2), 424-433.

Egan, M., Hortacsu, A. \& Matvos, G. (2015). Deposit Competition and Financial Fragility: Evidence from the US Banking Sector. The University of Chicago, Booth School of Business. Chicago: Fama-Miller Center for Research in Finance.

Fadare, S. (2011). Banking Crisis and Financial Stability in Nigeria. International Research Journal of Finance and Economics, 63, 1-12.

Garcia-Torea, N., Fernandez-Feijoo, B. \& de la Cuesta, M. (2016). Board of Director's Effectiveness and the Stakeholder Perspective of Corporate Governance: Do Effective Boards Promote the Interests of Shareholders and Stakeholders? Business Research Quarterly, 19, 246-260.

Garuba, A. O. \& Otomewo, G. O. (2015). Corporate Governance in the Nigerian Banking Industry: Issues and Challenges. African Research Review, 9(2), 104-117.

Geng, R., Bose, I. \& Chen, X. (2015). Prediction of Financial Distress: An Empirical Study of Listed Chinese Companies Using Data Mining. European Journal of Operational Research, 241, 236-247.

Goldstein, I. \& Pauzner, A. (2005). Demand-Deposit Contracts and the Probability of Banks Runs. The Journal of Finance, LX(3), 1293-1327.

Haldane, A. (2012). A Leaf Being Turned. A Speech Given by Andrew. G. Heldane, Executive Director, Financial Stability and Member of the Financial Policy Committee to Occupy Economics, "Socially Useful Banking" at Friend's House, London.

Hecko, H. (2007). Financial Intermediationin the Pre-Consolidated Banking Sector in Nigeria. World Bank

Heremans, D. (2007). Corporate Governance Issues for Banks: A Financial Stability Perspective. Centre for Economic Studies, Department of Economics, Faculty of Economics and Applied Economics, Discussion Paper Series.

Hoggarth, G., Reis, R., \& Saporta, V. (2002). Costs of Banking System Instability: Some Empirical Evidence. Journal of Banking and Finance, 26, 825-850.

Idam, L. E. (2015). Corporate Governance in Nigerian Banks: A Critical Review. IOSR Journal of Business and Management, 17(2), 54-61.

Iqbal, J., Strobl, S., \& Vahamaa, S. (2015). Corporate Governance and the Systemic Risk of Financial Institutions. Journal of Economics and Business, 82, 42-61. 
James, O. \& Okafor, C. O. (2011). Corporate Governance Mechanism and Firm's Financial Performance in Nigeria. Journal of Accounting Research, 1(1), 12-18.

Johnson, A. L. \& Kuosmanen, T. (2012). One-Stage and Two-Stage DEA Estimation of the Effects of Contextual Variables. European Journal of Operational Research, 220, 559-570.

Kajola, S. (2008). Corporate Governance and Firm Performance: The Case of Nigeria Listed Firms. European Journal of Economics, Finance and Administrative Science, 14, 16-28.

Kirkpatrick, G. (2009). The Corporate Governance Lessons from the Financial Crisis. Working Paper, OECD.

Koutsomanoli-Filippaki, A. I., \& Mamatzakis, E. C. (2011). Efficiency under Quantile Regression: What is the Relationship with Risk in the EU Banking Industry. Review of Financial Economics, 20, 84-95.

Kumar, S. \& Gulati, R. (2008). An Examination of Technical, Pure Technical, and Scale Efficiencies in India Public Sector Banks using Data Envelopment Analysis. Eurasian Journal of Business and Economics, 1 (2), 33-69.

Lakshan, A. M. \& Wijekoon, W. M. (2012). Corporate Governance and Corporate Failure. Procedia Economics and Finance, 2, 191-198.

Lang, M. \& Schmidt, P. G. (2016). The Early Warnings of Banking Crises: Interaction of Broad Liquidity and Demand Deposits. Journal of International Money and Finance, 61, 1-29.

Letza, S., Sun, X. \& Kirkbride, J. (2004). Shareholding Versus Stakeholding: A Critical Review of Corporate Governance. Corporate Governance: An International Review, 12(3), 242-263.

Li, Z., Crooks, J. \& Andreeva, G. (2014). Chinese Companies Distress Prediction: An Application of Data Envelopment Analysis. Journal of the Operational Research Society, 65, 466-479.

Liu, M. L. \& Miu, P. (2010). A Hybrid Bankruptcy Prediction Model with Dynamic Leadings on AccountingRatio-Based and Market-Based Information: A Binary Quantile Regression Approach. Journal of Empirical Finance, 17, 818-833.

Manzaneque, M., Priego, A. M. \& Merino, E. (2016). Corporate Governance Effect on Financial Distress Likelihood: Evidence from Spain. Spanish Accounting Review, 19(1), 111-121.

McDonald, J. (2009). Using Linear Square and Tobit in Second Stage DEA Efficiency Analysis. European Journal of Operational Research, 197(2), 792-798.

Money, K. \& Schepers, H. (2007). Are CSR and Corporate Governance Converging? A View from Boardroom Directors and Company Secretaries in FTSE 100 Companies in UK. Journal of General Management, 33 (2), 1-11.

Munisi, G. \& Randoy, T. (2013). Corporate Governance and Company Performance across Sub-Saharan African Countries. Journal of Economics and Business, 70, 92-110.

Ohlson, J. A. (1980). Financial Ratios and the Probabilistic Prediction of Bankruptcy. Journal of Accounting Research, 18(1), 109-131.

Organization for Economic Cooperation and Development. (1999). Principle of Corporate Governance. Paris: OECD.

Osaze, B. E. (2011). The Specificities of Value Melt-Down in the Nigerian Stock Exchange 2008-2010: Some Parallax Snaps. Benin: University of Benin.

Osaze, B. E. \& Anao, A. R. (1990). Managerial Finance. Benin: UNIBEN Press.

Papke, L. E. \& Wooldridge, J. M. (2008). Panel Data Methods for Fractional Response Variables with an Application to Test Pass Rates. Journal of Econometrics, 145, 121-133.

Parente, P. \& Santos-Silva, J. (2016). Quantile Regression with Clustered Data. Journal of Econometric Methods, 5(1), 1-15.

Pericoli, F. M., Pierucci, E. \& Ventura, L. (2013). Cross-Border Equity Portfolio Choices and the Diversification Motive: A Fractional Regression Approach. Economic Letters, 121(2), 282-286.

Powell, D. (2014). Did the Economic Stimulus Payments of 2008 reduce Labour Supply ? Evidence from Quantile Panel Data Estimation. RAND Corporation.

Powell, D. (2016). Quantile Treatment Effects in the Presence of Covariates. RAND Corporation.

Premachandra, I. M., Bhabra, G. S., \& Sueyoshi, T. (2009). DEA as a Tool for Bankruptcy Assessment: A Comparative Study with Logistic Regression Technique. European Journal of Operational Research, 193, 412-424.

Premachandra, I. M., Chen, Y. \& Watson, J. (2011). DEA as a Tool for predicting Corporate Failure and Success: A Case of Bankruptcy Assessment. Omega, 39(6), 620-626.

Rezaee, Z. (2007). Corporate Governance Post Sarbanes-Oxley, Regulations, Requirements and Integrated Processes. Hoboken, New Jersey: John Wiley \& Sons Inc. 
Rezaee, Z. \& Riley, R. (2010). Financial Statement Fraud: Prevention and Detection (2nd ed.). New Jersey: Wiley.

Rousseliere, D. (2014). A Flexible Approach to Efficiency Analysis with Multiple Treatments: Using Multiple Imputation and Quantile Regression to Estimate the Impact of Quality on the Efficiency of Cooperatives. Retrieved March 13, 2017, from www.sfer.asso.fr

Rygh, A. (2016). Corporate Governance and International Business. Essays on Multinational Enterprises, Ownership, Finance and Institutions. Retrieved January 18, 2017, from http://brage.bibssys,no/bi

Sanda, A. U., Mikailu, A. S. \& Tukur, G. (2005). Corporate Governance Mechanism and Firm Financial Performance in Nigeria. Nairobi: AERC Research Paper 149.

Sanusi, L. (2010). Global Financial Meltdown and the Reforms in the Nigerian Banking Sector. Being a Paper Delivered at the Convocation Ceremonies, ATBU Bauchi. Bauchi: Abubakar Tafawa Balewa University.

Sanusi, L. S. (2011). Banks in Nigeria and National Economic Development: A Critical Review. A Lecture at the Canadian High Commission in Collaboration with the Chartered Institute of Bankers of Nigeria and the Royal Bank of Canada, Abuja.

Sealey, C. \& Lindley, J. T. (1977). Inputs, Outputs and a Theory of Production and Cost at Depository Financial Institutions. Journal of Finance, 32, 1251-1266.

Shawtari, F. A., Salem, M. A., Hussain, H. I., Alaeddin, O. \& Thabit, O. B. (2016). Corporate Governance and Valuation: Inferences from Quantile Regression. Journal of Economics, Finance and Administrative Science, 21, 81-88.

Shehzad, C. T., de Hann, J. \& Scholtens, B. (2010). The Impact of Bank Ownership Concentration onImpaired Loans and Capital Adequacy. Journal of Banking and Finance, 34, 399-408.

Shetty, U., Pakkala, T. P. \& Mallikarjunappa, T. (2012). A Modified Directional Distance Formulation of DEA to Assess Bankruptcy: An Application to IT/ITES Companies in India. Expert Systems with Applications, 3, 1988-1997.

Shiri, M. M. \& Salehi, M. (2012). Prediction of Financial Distress in Tehran Stock Exchange Using DEA Approach. Indian Journal of Science and Technology, 5(10), 3461-3473.

Simar, L. \& Wilson, P. W. (2007). Estimation and Inference in Two-Stage, Semi-Parametric Models of Production Processes. Journal of Econometrics, 136(1), 31-64.

Simar, L. \& Wilson, P. W. (2011). Two Stage DEA: Caveat Emptor. Journal of Productivity Analysis, 36, 205-218.

Simpson, W. G. \& Gleason, A. E. (1999). Board Structure, Ownership and Financial Distress in Banking Firms. International Review of Economics and Finance, 8(3), 281-292.

Thomas, I. \& Mohammed, D. (2011). The Impact of Capital Structure and Corporate Governance on the Performance of Nigerian Commercial Banks. Journal of Accounting Research, 1(1), 16-24.

Uche, C. (2014). Corporate Governance in Nigeria Financial Industry. Chartered Institute of Bankers of Nigeria Journal, 2, 11-23.

Villanueva-Villar, M., Rivo-Lopez, E., \& Lago-Penas, S. (2016). On the Relationship between Corporate Governance and Value Creation in an Economic Crisis: Empirical Evidence for the Spanish Case. Business Research Quartely, 19, 233-245.

Wang, T. \& Hsu, C. (2013). Board Composition and Operational Risk Events of Financial Institutions. Journal of Banking and Finance, 37, 2042-2051.

Wanke, P., Barros, C. P. \& Faria, J. R. (2015). Financial Distress Drivers in Brazillian Banks: A Dynamic Slack Approach. European Journal of Operational Research, 240(1), 258-268.

Wernerfelt, B. (1984). A Resource Based View of the Firm. Strategic Management Journal, 5(2), 171-180.

$\mathrm{Xu}, \mathrm{Z}$. (2007). The Structure of Ownership and Corporate Governance. The Case of Chinese Listed Companies. Retrieved March 13, 2017, from http://bura.brunel.ac.uk/handle/2438/5357

Zeitun, R. (2009). Ownership structure, corporate performance and failure: evidence from panel data of emerging market the case of Jordan. Corporate Ownership and Control, 6(4), 96-114. 